\title{
Isolation, Cloning and Sequence Analysis of 1-Aminocyclopropane-1- Carboxylate Deaminase Gene from Native Sinorhizobium meliloti
}

\author{
Houshang Khosravi 1,*, Hossein Ali Alikhani ${ }^{2}$, Bagher Yakhchali ${ }^{3}$, Ali Asghar Kharkhane ${ }^{3}$ \\ ${ }^{1}$ Deparment of Soil Biology, Soil and Water Research Institute, P.O. Box 31788-311, Karaj, I.R. IRAN \\ ${ }^{2}$ Department of Soil Science, Faculty of Agriculture, University of Tehran, Karaj, I.R. IRAN \\ ${ }^{3}$ National Institutes of Genetic Engineering and Biotechnology, P.O. Box 14965/161, Tehran, I.R. IRAN \\ *Corresponding author: Houshang Khosravi, Deparment of Soil Biology, Soil and Water Research Institute, Karaj, I.R. \\ IRAN. P.O. Box 31788-311, Tel: +98-2636203502, Fax:+98-2636210121, E-mail: hkhosravi@swri.ir
}

Received: February 05, 2013; Revised: September 06, 2014

Background: Many plant growth-promoting bacteria including Rhizobia contain the 1-aminocyclopropane-1-carboxylate
(ACC) deaminase enzyme that can leave ACC, and thereby lower the level of ethylene in stressed plants. Drought and salin-
ity are the most common environmental stress factors for plants in Iran.
Objectives: The main aim of this research was development of bio-fertilizers containing ACC deaminase enzyme which is
very important in conditions of stressed drought and salinity.
Materials and Methods: In this research 168 isolates of native Sinorhizobium meliloti were evaluated for ACC deaminase
activity. These isolates were classified in four groups based on growth rate on ACC containing medium and enzyme activ-
ity. One isolate from each group was selected for molecular characterization. The nucleotide sequence of $16 \mathrm{~S}$ rRNA gene
of the selected isolates were determined. The ACC deaminase genes (acdS) on total and chromosomal DNA of $S$. meliloti
KYA40, and KYA71 strains were isolated and cloned in pTZ57R/T vector and the obtained recombinant plasmids were used
for sequence analysis.
Results: The sequence of acdS genes from strains KYA71 and KYA40 and corresponding proteins were analyzed with
respect to available sequences in NCBI database. The $16 \mathrm{~S}$ rRNA gene sequences of $S$. meliloti strains submitted to the
GeneBank/NCBI database. The acdS gene of KYA71 may be located on chromosomal DNA and in KYA40 it is located on
one of the mega plasmids. These two genes have $99 \%$ similarity with three nucleotide differences which only lead to a
change in one amino acid 48, threonine in KYA40 acdS gene and methionine in KYA71.
Conclusions: The comparison of amino acid sequences of KYA40 and KYA71 with other sequences in the database showed
that the amino acids 37 to 58 in almost all strains were similar. Therefore, it was concluded that it was a conserved region
in this location of $a c d S$ genes and any changes in this region may cause change in ACC deaminase activity.
Keywords: ACC deaminase; acdS gene; Sinorhizobium meliloti

\section{Background}

Ethylene is an important hormone for the normal growth and development of plants, developments such as root elongation, senescence, fruit ripening, etc. However, when this hormone is present at high concentration, for example in stressed conditions, it can be damaging for plants (1). Plant growth promoting rhizobacteria (PGPR) are a group of soil bacteria that can stimulate the growth of plants through various mechanisms such as nitrogen fixation, synthesizing phytohormones or solubilizing phosphates (2). Many PGPRs contain the enzyme 1-aminocyclo- propane-1-carboxylate (ACC) deaminase. This enzyme can cleave ACC, the precursor of ethylene, to $\alpha$-ketobutyrate and ammonium (3) and thereby lower the level of ethylene in stressed plants (4). This process enables microorganisms to grow on a minimal medium containing ACC as the sole nitrogen source. The low levels of ethylene by ACC deaminase is considered one of the most important mechanisms employed by plant growth-promoting bacteria to facilitate plant growth under environmental stress conditions such as salinity (5), flooding (6) and drought (7). Rhizobia such as Sinorhizobium meliloti are well 
known as nitrogen fixing bacteria and have a symbiotic relation with root of legume plants. Some Rhizobia contain the enzyme ACC deaminase (15). Drought and salinity are the most common environmental stress factors for plants in Iran, where about $75 \%$ of the land area is semi-arid or arid and the total saline soils are approximately 55.6 Mha (about $34 \%$ of the land area) $(8,9)$. Therefore, development of biofertilizers containing ACC deaminase enzyme will be very important in these stressed conditions in Iran. In this research, some indigenous Sinorhizobium meliloti strains were investigated for ACC deaminase enzyme activity. Four strains were selected for further investigation. We sequenced 16S rRNA and ACC deaminase $(a c d S)$ gene of these strains. The sequence of 16S rRNA gene has been widely used as a molecular tool to estimate relationships among bacteria (phylogeny), but more recently it has also become important as a means to identify an unknown bacterium to the genus or species level. We postulated that these strains have ACC deaminase activity. Here we describe isolation, cloning and sequence of acdS gene of Sinorhizobium meliloti KYA40 and KYA71 strains.

\section{Objectives}

The main objectives of this study was th evaluation of 1-aminocyclopropane-1-carboxylate (ACC) deaminase genes (acds) for further studying of environmental stresses such as dry and saline soils in future investigations.

\section{Materials and Methods}

\subsection{Isolation of ACC-utilizing strains}

One hundred and sixty eight strains of Sinorhizobium meliloti were obtained from the collection of Soil and Water Research Institute of Iran. Before assaying the ACC deaminase activity of strains they were screened on ACC containing Rhizobium minimal medium (RMM) and classified based on the growth rate by measuring the difference between colony diameter on ACC and control plates. Three series of plates were prepared; 1. RMM (as a negative control). 2. RMM supplemented with $150 \mu \mathrm{L}$ of $0.3 \mathrm{M}$ ACC, 3 . RMM supplemented with $150 \mu \mathrm{L}$ of $0.3 \mathrm{M} \mathrm{NH}_{4} \mathrm{Cl}$ (as a positive control). The colony diameter was measured after 4 days incubation at $28^{\circ} \mathrm{C}$. One strain of each group was selected for further investigation.

Solution 1 and 2 autoclaved separately. Thesolution 3 filter-sterilized through a 0.2 ìmmembrane andadded to mixed medium at about $50^{\circ} \mathrm{C}$ (Table 1).

\subsection{Genomic and total DNA preparation}

Pure cultures of Sinorhizobium meliloti isolates were grown in $50 \mathrm{ml}$ conical flasks containing 25 $\mathrm{ml}$ of Yeast Extract Mannitol Broth medium (12). The cells from $5 \mathrm{ml}$ were pelleted in a bench centrifuge $\left(7500 \mathrm{~g}\right.$ in $10 \mathrm{~min}$ in $\left.4^{\circ} \mathrm{C}\right)$ and the resuspended pellets $(50 \mu \mathrm{L})$ were transferred into 1.5 $\mathrm{ml}$ centrifuge tubes, followed by washing the cells three times with $500 \mu \mathrm{L}$ TE buffer $(10 \mathrm{mM}$ Tris $\mathrm{HCl}, 1 \mathrm{mM}$ EDTA, pH 8.0). The cells were re-suspended in $100 \mu \mathrm{L}$ of a solution containing $25 \%$ sucrose, $1 \mathrm{mg} / \mathrm{ml}$ lysosyme, $10 \mathrm{mM}$ Tris $\mathrm{HCl}, \mathrm{pH}$ 8.0 at $37^{\circ} \mathrm{C}$ for $15 \mathrm{~min}$. The lysate was mixed gently with $150 \mu \mathrm{L}$ of $7.5 \mathrm{M}$ ammonium acetate and mixture was extracted with $500 \mu \mathrm{L}$ of chloroform/isoamyl alcohol $(24: 1, \mathrm{v} / \mathrm{v})$ by mixing and centrifuging in $9500 \mathrm{~g}$ for $10 \mathrm{~min}$. The aqueous layer was transferred to a clean $1.5 \mathrm{~mL}$ centrifuge tube and the DNA was precipitated by propanol. DNA was washed twice in $100 \mu \mathrm{L} 70 \%$ ethanol and then resolved in $20 \mu \mathrm{L}$ of TE buffer (13). For preparation of total DNA from Sinorhizobium meliloti about $100 \mu \mathrm{L}$ of culture was centrifuged at $9500 \mathrm{~g}$ for 3 minute. The cells were re-suspend-

Table 1. Rhizobium minimal medium (RMM)

\begin{tabular}{lcc}
\hline Solution & Compound & Amount \\
\hline & $\mathrm{K}_{2} \mathrm{HPO}_{4}$ & $2.05 \mathrm{gr}$ \\
$\mathrm{KH}_{2} \mathrm{PO}_{4}$ & $1.45 \mathrm{gr}$ \\
& Distilled water & $200 \mathrm{ml}$ \\
& $\mathrm{NaCl}$ & $0.15 \mathrm{gr}$ \\
& $\mathrm{CaCl}_{2}$ & $0.01 \mathrm{gr}$ \\
& $\mathrm{MgSO}_{4} \cdot 7 \mathrm{H}_{2} \mathrm{O}$ & $0.5 \mathrm{gr}$ \\
2) & Mannitol & $10.0 \mathrm{gr}$ \\
& Microelements solution & $0.5 \mathrm{ml}$ \\
& Distilled water & $800 \mathrm{ml}$ \\
& Agar & $15 \mathrm{gr}$ \\
& Pantathonic acid & $1 \mathrm{mg} / \mathrm{ml}$ \\
3) & Biotin & $1 \mathrm{mg} / \mathrm{ml}$ \\
& Thiamine & $1 \mathrm{mg} / \mathrm{ml}$ \\
\hline
\end{tabular}


ed in $50 \mu \mathrm{L}$ distilled water and boiled for $5 \mathrm{~min}$ utes and centrifuged at $9500 \mathrm{rpm}$ for 5 minute. 2 $\mu \mathrm{L}$ of the supernatant was used as template in 25 $\mu \mathrm{L}$ PCR reaction.

\subsection{Amplification and sequencing of $16 \mathrm{~S} r R N A$}

The universal Primers, fD1 5' AGAGTTTGATCCTGGCTCAG $3^{\prime}$ and rD1 5'AAGGAGGTGATCCAGCC 3' (14) were used for PCR amplification of 16S rRNA gene. PCR products were cleaned by High Pure PCR Product Purification Kit (Roche Molecular Biochemicals, Mannheim, Germany). The partial nucleotide sequences of the 16S rRNA gene were determined by direct sequencing of appropriate PCR products using $\mathrm{fD} 1$ and $\mathrm{rD} 1$ primers. The sequences of $16 \mathrm{~S}$ rRNA were compared with sequences from NCBI Gene Bank database.

\subsection{Amplification, cloning and expression of $A C C$ deaminase (acdS) gene}

Two specific primers ACCDF: 5'-ATGTCACTGTTGGAAAAGTTCGA-3' and ACCDR: 5' TCAGCCGTCCCTGTAATAGC-3' were designed for amplification of the ACC deaminase gene (Analysed by OligoAnalyzer 3.1). The genomic and total DNAs of four strains were used as a template in the PCR reaction. The following temperature profiles were used for PCR amplification: $95^{\circ} \mathrm{C}$ for $5 \mathrm{~min}$ for an initial denaturation; 30 cycles of denaturation; at $94^{\circ} \mathrm{C}$ for $1 \mathrm{~min}$, annealing at $53^{\circ} \mathrm{C}$ for $1.5 \mathrm{~min}$, extension at $72^{\circ} \mathrm{C}$ for 1.5 min, and a final extension at $72^{\circ} \mathrm{C}$ for $10 \mathrm{~min}$. The pfu DNA polymerase was used for DNA amplification in PCR. PCR products were purified by High Pure PCR Product Purification Kit, (Roche, Cat. No. 11732668001). The pure PCR products were evaluated by electrophoresis on $1 \%$ agarose gel. The PCR products of ACC deaminase $(a c d S)$ gene were extended at $72^{\circ} \mathrm{C}$ for $30 \mathrm{~min}$ by taq DNA polymerase and dATP for A-end tailing. The high purified PCR products were ligated to pTZ57R/T cloning plasmid (Fermentas, Germany) and transformed into $E$. coli DH5 $\alpha$. The transformants were spreaded on LB agar medium containing IPTG, Xgal and Ampicilin and incubated at $37^{\circ} \mathrm{C}$ for $16 \mathrm{~h}$. Four white colonies were selected and cultured in LB medium and incubated at $37^{\circ} \mathrm{C}$ for $24 \mathrm{~h}$. The transformants were evaluated for inserted DNA by PCR using universal M13-pUC primers: Forward (17mer): 5'-d (GTTTTCCCAGTCACGAC)-3', Reverse (17mer): 5'-d(CAGGAAACAGCTATGAC)-3'

One of the white colonies that received inserted fragment of the acdS gene was confirmed by PCR using ACCDF and ACCDR primers. The recombinant plasmids containing $a c d S$ were sequenced for ultimate confirmation.

\subsection{ACC deaminase activity}

The strains were grown in Yeast Extract Manitol Broth medium to late log phase before the cells were harvested by centrifugation $(8000 \mathrm{rpm}$ in $10 \mathrm{~min})$, washed with $0.1 \mathrm{M}$ Tris- $\mathrm{HCl}(\mathrm{pH}=8.5)$ and incubated in $\mathrm{RMM}$ containing $\mathrm{ACC}$ as the sole source of nitrogen for $24 \mathrm{~h}$. The bacterial cells were collected, re-suspended in $0.1 \mathrm{M}$ Tris$\mathrm{HCl}, 30 \mu \mathrm{L}$ toluene were added to the cell suspension. The toluenized cells were divided in two aliquots. In one aliquot, ACC deaminase activity was assayed immediately by adding $0.5 \mathrm{M}$ ACC and $\alpha$-ketobutyrate is derivative as a phenyhydrazone and then the absorbance is measured at 540 $\mathrm{nm}(3,10)$. In another aliquot of toluenized cells, the total protein was assayed by by Bradford method (11) using bovine serum albumin as standard. One unit of ACC deaminase activity identified as formation of $1 \mathrm{nmol}$ of $\alpha$-ketobutyrate per $\mathrm{mg}$ protein per hour under these conditions.

\section{Results}

\subsection{ACC deaminase activity of strains}

From 168 isolates, 77 isolates were able to grow on ACC containing medium. Based on the colony diameter of isolates on RMM medium, strains were categorized in four groups, zero, $<2$, 2-6 and $>6 \mathrm{~mm}$. (Table 2).

Twenty strains of 168 strains (five strains fromeach group) including high, medium, weak and nogrowth were selected for future investigation. These strains were selected based on other similar morphological and physiological characteristics (data not shown).

Different strains obtained on ACC containingmedium showed differences in their deaminase activities, as shown in Table 3 . The results showed that, ACC deaminase activity of strains was 0-326 nmol of $\alpha$-ketobutyrate $\mathrm{mg}^{-1}$ protein $\mathrm{h}^{-1}$ (Table 3 ).

Four strains of Sinorhizobium meliloti KYA40 
(with maximum growth on ACC agar and 136 nmol $\alpha$-ketobutyrate mg- $^{-1}$ protein. ${ }^{-1}$ ), KYA71 (with medium growth on ACC agar and $326 \mathrm{nmol}$ $\alpha$-ketobutyrate mg-1 $^{-1}$ protein.h-1), KYA27 (with weak growth on ACC agar and no ACC deaminase activity), and KYA95 (with no growth on ACC agar and no ACC deaminase activity) were selected for molecular investigations.

\subsection{Analysis of $16 \mathrm{~S}$ rRNA genes}

PCR with universal Primers, fD1 and rD1 resulted in $1500 \mathrm{bp}$ fragment of $16 \mathrm{~S}$ rRNA gene sequence (Figure 1.). The sequences were subjected to BLAST (Basic Local Alignment Search Tool) in NCBI data base to compare a DNA sequence with DNA sequences in the database which showed that these strains are Sinorhizobium meliloti.

The 16S rRNA gene sequences of Sinorhizobium meliloti strains were submitted to the GeneBank/NCBI database under the accession numbers of EU625296 (S. meliloti KYA27), EU603723 (S. meliloti KYA40), EU603721 (S. meliloti KYA71) and EU625297 (S. meliloti KYA95).

A $1.5 \mathrm{~kb}$ fragment of $16 \mathrm{~S}$ rRNA for each strain was detected. Ethidiombromid stained agarose gel of the PCR products of $16 \mathrm{~S}$ rRNA showed in Figure 1.

\subsection{ACC deaminase genes}

PCR with the primers ACCDF and ACCDR resulted in $1020 \mathrm{bp}$ fragment for strains KYA40 and KYA71. The Ethidium bromide stained Agarose gel of the PCR products of ACC deaminase gene in strain KYA40 and KYA71 are shown in Figure 2 for colony PCR and in Figure 3 for genomic DNA.

The sequence analysis and BLAST search in NCBI revealed that these fragments are ACC deaminase gene. The sequence of $a c d S$ genes from strains KYA71 and KYA40 submitted to the GeneBank/NCBI database under the accession numbers of KYA71 (EU003994) and KYA40 (EU603722).

\section{Discussion}

The 16S rRNA evaluation of the strains revealed that the bacteria used in this study are sinorhizobium melioloti and this means that the previous biochemical tests for identification of these bacteria were accurate. The results of the present study clearly demonstrated that some of Sinorhizobium meliloti strains native to soils of Iran contain ACC deaminase enzyme. The first presence of ACC deaminase in Rhizobia was reported by $\mathrm{Ma}$ and colleague (15). Peters and Crist-Estes reportedthat ethylene inhibits nodule development in alfalfa (Medicago sativa) (16). It was reported that strains of rhizobia that have ACC deaminase enzyme may have the ability to lower ethylene levels in their host specific legumes and overcome some of the negative effects of ethylene on nodulation. Ma et al., (17) reported that Sinorhizobium meliloti containing ACC deaminase-producing activity showed 35$40 \%$ greater efficiency in modulating of alfalfa than strain without ACC deaminase activity. Hence the ACC deaminase containing Sinorhizobium meliloti strains obtained from this research can be used for future investigation and inoculation of alfalfa in salinity and drought stress conditions in Iran. Therefore these genes may be

Table 2. Classification of isolates based on growth on ACC containing medium

\begin{tabular}{lcccccccccc}
\hline Bacterial group & Colony diameter & $\begin{array}{c}\text { Growth rate } \\
\text { on ACC agar }\end{array}$ & No of Isolates & & Selected strains \\
\hline 1 & $>6$ & High & 5 & KYA166 & KYA130 & KYA44 & KYA40 & KYA5 \\
\hline 2 & $2-6$ & Medium & 23 & KYA49 & KYA62 & KYA97 & KYA71 & KYA 60 \\
\hline 3 & $<2$ & Weak & 49 & KYA74 & KYA45 & KYA15 & KYA64 & KYA27 \\
\hline 4 & 0 & No growth & 91 & KYA72 & KYA43 & KYA37 & KYA58 & KYA95 \\
\hline
\end{tabular}




\begin{tabular}{lccc}
\hline \multicolumn{4}{l}{ Table 3. ACC deaminase activity } \\
\hline $\begin{array}{l}\text { Bacterial } \\
\text { strain }\end{array}$ & $\begin{array}{c}\text { ACC deaminase } \\
\text { activity* }\end{array}$ & $\begin{array}{c}\text { Bacterial } \\
\text { strain }\end{array}$ & $\begin{array}{c}\text { ACC deaminase } \\
\text { activity* }\end{array}$ \\
\hline KYA5 & 125 & KYA60 & 200 \\
KYA15 & 0 & KYA62 & 192 \\
KYA27 & 0 & KYA64 & 0 \\
KYA37 & 0 & KYA71 & 326 \\
KYA40 & 136 & KYA72 & 0 \\
KYA43 & 0 & KYA74 & 0 \\
KYA44 & 201 & KYA95 & 0 \\
KYA45 & 0 & KYA97 & 135 \\
KYA49 & 127 & KYA130 & 135 \\
KYA58 & 0 & KYA166 & 135 \\
\hline
\end{tabular}

used for transferring to other bacteria or producing transgenic plants. Based on the PCR amplification of acdS gene by two methods colony PCR and genomic DNA, it is concluded that the acdS gene of KYA71 may be located on chromosomal DNA and in KYA40 is on one of mega plasmids. (18) reported that acdS gene of $R$. leguminisarum bv viciae $128 \mathrm{C} 53 \mathrm{~K}$ is located on one of the endogenous large plasmids.

These two genes had $99 \%$ similarity with three

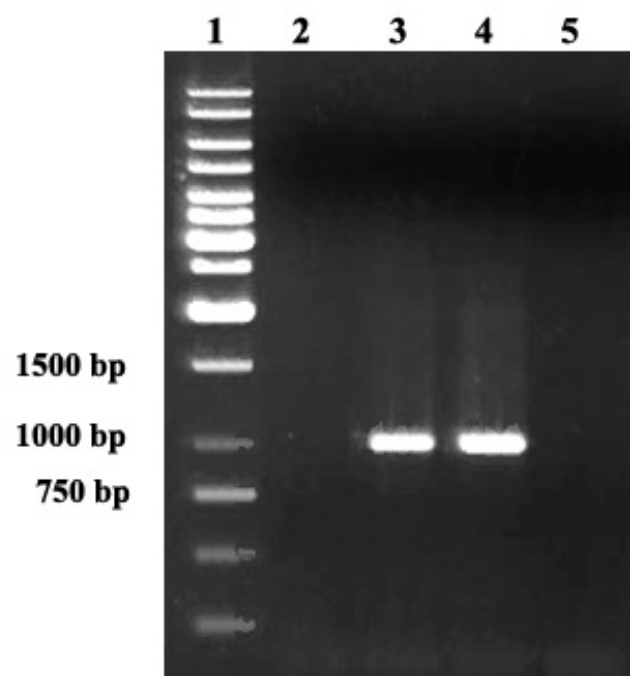

Figure 2. Ethidium bromide stained agarose gel of the PCR products of ACC deaminase gene of colony PCR, Lane 1:1 kb DNA ladder, lane 2: KYA27, lane 3: KYA40, lane 4: KYA71, lane 5: KYA95
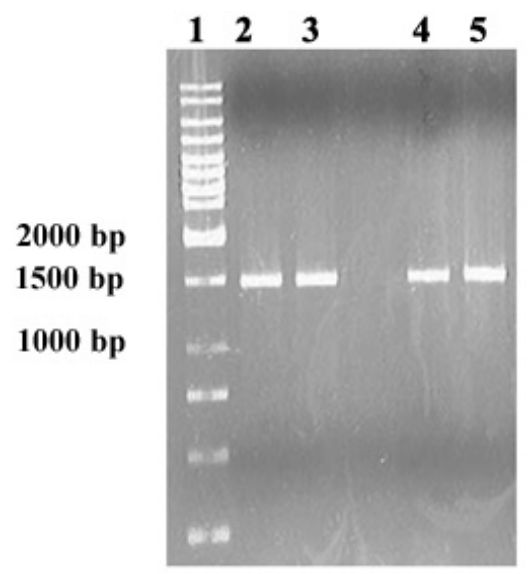

Figure 1. Ethidium bromide stained agarose gel of the PCR products of 16S rRNA (Lane 1:1 kb DNA ladder, Lane 2: YYA27, Lane 3: KYA40, Lane 4: KYA71, Lane 5: KYA95)

nucleotide differences (Table 4), which only lead to change in one amino acid 48, threonine in KYA40 acdS gene and methionine in KYA71.

Two genes has $86 \%$ identity with Sinorhizobium meliloti plasmid pSmeSM11a and $85 \%$ with Rhizobium leguminosarum bv. viciae plasmid pRL10. Hontzeas et al., (19) reported that substitution of Asp44 with Gly44 by point mutation causes deactivation ACC deaminase activity. They concluded that the highly conserve Gly44 is important in gating ACC (substrate) entry enzyme's active site.

The comparison of amino acid sequences of acdS gene of KYA40 and KYA71 with other

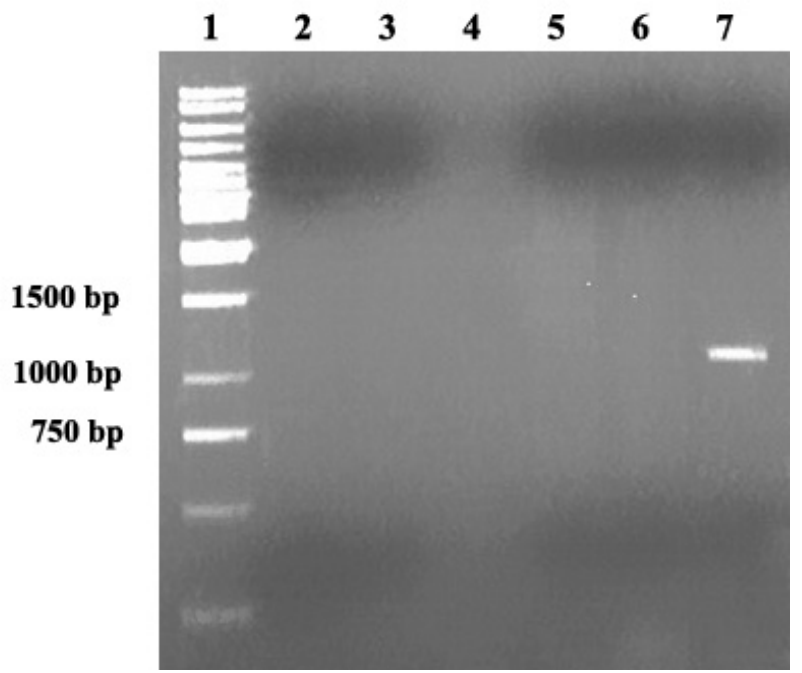

Figure 3. Ethidium bromide stained agarose gel of the PCR products of ACC deaminase gene of Genomic DNA, Lane 1:1 kb DNA ladder, lane 2 and 3: KYA95, lane 4 and 5: KYA27, lane 6: KYA40, lane 7: KYA71 
Table 4. Nucleotide differences between acdS genes of KYA40 and KYA71

\begin{tabular}{|c|c|c|}
\hline \multicolumn{2}{|c|}{ Nucleotide differences } & \multirow[t]{2}{*}{ Nucleotide number } \\
\hline $\operatorname{acdS} 40$ & $\operatorname{acdS71}$ & \\
\hline $\mathrm{T}$ & C & 143 \\
\hline C & $\mathrm{T}$ & 195 \\
\hline $\mathrm{T}$ & C & 879 \\
\hline
\end{tabular}

sequences in database showed that the amino acids 37 to 58 in almost all strains are similar (Figure 4).

Therefore, it is concluded that it may be a conserve region in $a c d S$ genes and any changes in this region may cause change in ACC deaminase activity. Shah et al., (20) showed that the codons used by ACC deaminase genes of Pseudomonas putida, P. fluorecens and Enterobacter cloacae are highly conserved. Duan et al., (22) reported relatively little diversity in ACC deaminase genes of some Rhizobium strains isolated from a wide geographic area.

\section{Acknowledgments}

Sinorhizobium meliloti KYA40
Sinorhizobium meliloti KYA71
Sinorhizobium meliloti nodulating alfalfa
Sinorhizobium medicae WSM419
Sinorhizobium sp.BL3
Rhizobium leguminosarum PB62
Rhizobium leguminosarum PB45
Rhizobium leguminosarum. by. viciae 3841
Rhizobium gallicum PB2
Bradurhizobium sp. BTAi1
Bradurhizobium sp. ORS278
Bradurhizobium japonicum USDA110
Azorhizobium caulinodans ORS 571
Mesorhizobium loti R7A
Mesorhizobium loti MAFF303099
Phyllobacterium brassicacearum STM19
Burkholderia cenocepacia PC184
Pseudomonas sp. strain 6G5
Pseudomonas fluorescens 2P24
Pseudomonas putida UW4
Methylobacterium sp. 4-46
Methylobacterium nodulans ORS 2060
Ralstonia pickettii $12 \mathrm{~J}$
Ralstonia eutropha H16
Acidovorax avenae subsp. citrulli AAC00-1
Pseudomonas syringae pv. syringae B728a
Enterobacter cloacae UW4
Polaromonas sp. JS666
Mycobacterium abscessus

The authors would like to thank all the staff of Soil Science Department of University of Tehran, National Institute of Genetic Engineering and Biotechnology and Soil and Water Research Institute of Iran.

\section{Authors Contribution}

The study concept, design, technical material and analysis of data within this study was conducted by Houshang Khosravi, Hossein Ali Alikhani, Bagher Yakhchali and some technical and material assistance was provided by Ali Asghar Kharkhane

\section{Financial Disclosure}

This research was financially supported by university of Tehran

\section{Funding/Support}

University of Tehran, National Institute of Genetic Engineering and Biotechnology and Soil and Water Research Institute financially supported this study and provided materials and equipments.

\section{References}

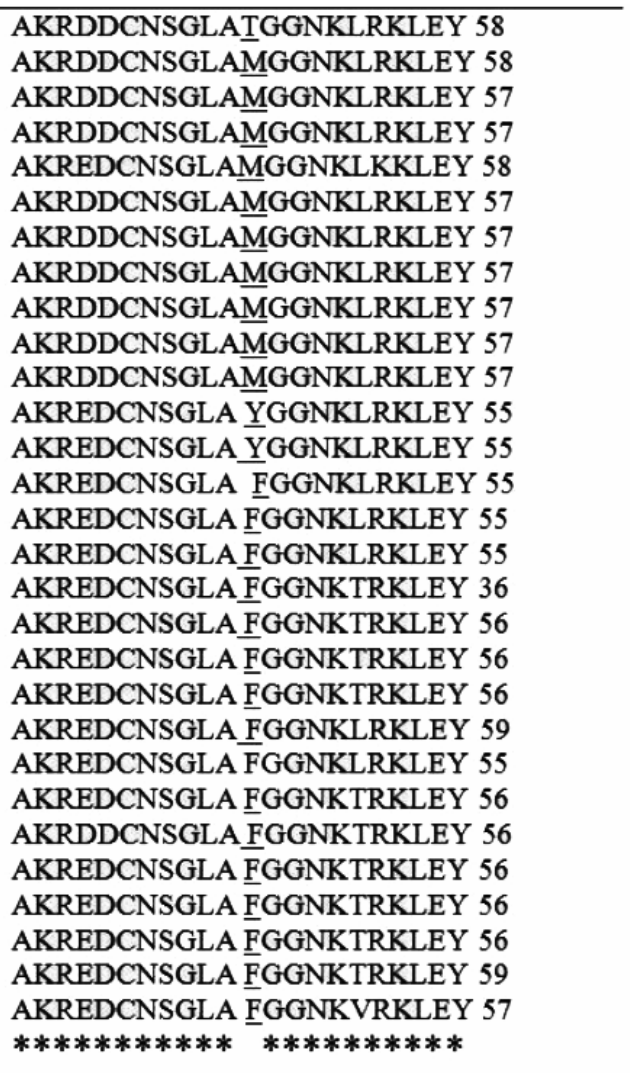

Figure 4. The comparison of amino acid sequences of KYA40 and KYA71 with other sequences in database 
1. Abeles FB, Morgan PW, Saltveit ME: The biosynthesis of ethylene. In: ethylene in plant biology, $2^{\text {nd }}$ edition edn: Academic Press;1992;PP:26-55.doi:10.1016/B978-0-08-0916286.50009-6

2. Glick BR: The enhancement of plant growth by free-living bacteria. Can J Micrbiol. 1995;41:109-117.doi:10.1139/m95-015

3. Honma M, Shimomura T: Metabolism of 1-aminocyclopropanel-carboxylate deaminase. Agricul Biol Chem. 1987;42:1825-1831. http://dx.doi.org/10.1271/bbb1961.42.1825

4. Glick BR, Penrose DM, Li J: A model for the lowerig of plant ethylene concentration by plant growth-promoting bacteria. $J$ Theor Biol. 1998;190:63-68.doi:10.1006/jtbi.1997.0532

5. Sergeeva E, Shah S, Glick BR: Growth of transgenic canola (Brassica napus cv. Wester) expressing a bacterial 1-aminocyclopropane-1-carboxylate (ACC) deaminase gene on high concentration of salt. World J Microbiol Biotechno. 2006;22:277282.10.1007/s11274-005-9032-1

6. Grichko VP, Glick BR: Ethylene and flooding stress in plants. Plant Physiol Biochem. 2001;39:1-9.doi:10.1016/S09819428(00)01213-4

7. Mayak S, Tirosh T, Glick BR: Plant growth-promoting bacteria that confer resistance to water stress in tomato and pepper. Plant Sci. 2004; 166:525-530.doi:10.1016/j.plantsci.2003.10.025

8. FAO. Global network on integrated soil management for sustainable use of salt- affected soils [http://www.fao.org/ag/agl/agII/spush/topic2.htm\#iran]

9. Moameni A. Geographical distribution and salinity levels of soil resources of Iran. Iran $J$ Soil Res. 2011;24(3):203-215.(In Persian).

10. Penrose DM, Glick B, R.: Methods for isolating and characterizing ACC deaminase-containing plant growth-promoting rhizobacteria. Physiol Plant. 2003;118:10-15.doi:10.1034/j.13993054.2003.00086.x

11. Bradford MM: The principle of protein-dye binding. A rapid and sensitive method for the quantitative of protein utilizing. Analitic Biochem. 1976;72:248-254.

12. Vincent JM. A manual for the practical study of rootnodule bacteria. London: Blackwell Scientific. 1970; PP: 440. doi: 10.1002/jobm.19720120524

13. Agrawal R, Bajoria S, Pareek RP: DNA isolation from Rhizobium by phenol chloroform method. Retrieved February 21 2012 from: http://www.protocolonline.org/prot/Protocols/DNAIsolation-from-Rhizobium-by-Phenol-ChloroformMethod-3440.html.

14. Weisburg WG, Brans SM, Pelletier DA. : 16S ribosomal DNA amplification for phylogenetic study. J Bacteriol. 1991;173:697-703.

15. Ma W, Sebestianova SB, Sebestian J, Burd GI, Guinel FC, Glick BR: Prevalence of 1-aminocyclopropaqne-1carboxylate deaminase in Rhizobium spp. Antony Van Leeuwenhoek. 2003;83:285-291.

16. Peters NK, Crist-Estes DK: Nodule formation is stimulated by the ethylene inhibitor aminoethoxyvinylglycine. Plant Physiol.1989;91(2):690-693.doi: http://dx.doi.org/10.1104/pp.91.2.690

17. Ma W, Charles TC, Glick BR: Expression of an exogenous 1- aminocyclopropane-1-carboxylate deaminase gene in Sinorhizobium meliloti increases its ability to modulate alfalfa. Appl Environ Microbiol. 2004;70:5891-5897.doi: 10.1128/AEM.70.10.5891-5897.2004

18. Ma W, Guinel FC, Glick BR: Rhizobium leguminosarum bv. viciae 1-aminocyclopropane-1- carboxylate deaminase promotes nodulation of pea plants. Applied Environ Microbiol. 2003;69:4396-4402.doi: 10.1128/AEM.69.8.4396-4402.2003

19. Hontzeas N, Zoidakis J, Glick BR, Abu-Omar MM: Expression and characterization of 1-aminocyclopropane-1-carboxylate deaminase from the rhizobacterium Pseudomonas putida UW4: A key enzyme in bacterial plant growth promotion. Biochimia et Biophysica Acta. 2004;1703:11-19.doi:10.1016/j.bbapap.2004.09.015

20. Shah S, Li J, Moffatt BA, Glick BR: Isolation and characterization of ACC deaminase genes from two different plant growth-promoting rhizobacteria. Can J Microbiol. 1998;44:833-843. doi:10.1139/w98-074

21. Duan J, Muller KM, Charles TC, Vesely S, Glick BR: 1-Aminocyclopropane-1-carboxylate (ACC) deaminase genes in rhizobia from southern saskatchewan. Microb Ecol. 2009;57:423-436. doi:10.1007/s00248008-9407-6 